УДК 37(091)(438)- 054.5

DOI:

Леся Шагала, кандидат педагогічних наук, старший викладач кафедри германських мов і перекладознавства Дрогобииького державного педагогічного університету імені Івана Франка

\title{
ЗАБЕЗПЕЧЕННЯ ОСВІТНІХ ПОТРЕБ ПРЕДСТАВНИКІВ УКРАЇНСЬКОЇ ГРОМАДИ У ЦЕНТРАХ ШКІЛЬНИЦТВА У ПОЛЬЩІ
}

Статтю присвячено ролі освітніх осередків у збереженні національної самобутності украйнської громади в умовах іншокультурного простору. Здійснено аналіз етапів розвитку украйнського шкільництва у Польщчі від середини ХХ до початку XXI cm. Окреслено напрялки та здобутки освітньо-виховної діяльності шкільних закладів, а також проблемні питання функиііонування культурно-освітніх осередків. Підкреслено значення рідної мови як вагомого чинника у прочесі консолідачії української меншини та у протистоянні асиміляиійним процесам.

Ключові слова: освітньо-виховна діяльність; украӥнське шкільництво; асиміляційний процес; украӥнська громада; національна самобутність.

Jim. 15.

Lesia Shahala, Ph.D.(Pedagogy), Senior Lecturer of the Germanic Languages and Translation Department Drohobych Ivan Franko State Pedagogical University

\section{SATISFYING THE EDUCATIONAL NEEDS OF UKRAINIAN COMMUNITY IN THE CENTRES OF SCHOOLING IN POLAND}

The article deals with the role of educational centres in preserving the national identity of the Ukrainian community in a foreign cultural environment. Schools with a native language education are of considerable importance, since the use of Ukrainian and the observance of traditions are the main factors in preserving culture.

The stages of the Ukrainian schooling development in Poland within the period from the mid-20th to the beginning of the $21 \mathrm{st} \mathrm{c}$. are analysed, the functioning of schooling centers under the conditions of interaction between the title Polish nation and the Ukrainian minority is considered. It has been found out that the dynamics of the formation of Ukrainian schooling in Poland as a system depended on socio-political factors. Numerous organizational and pedagogical approaches in the development of Ukrainian schooling are identified. It is noted that the study of Ukrainian takes place at different educational levels: preschool institutions, primary schools, grammar schools and general secondary lyceums. Attention is payed to a widespread form of language learning in Poland - Sunday schools. The fact of a special place of church organisations in preserving traditions is noted.The importance of the mother tongue as a major factor in hindering assimilation processes has been highlighted. The significance of the activities of such cultural and educational organizations as the Ukrainian Social and Cultural Society (later the Organization of Ukrainians in Poland) and the Ukrainian Teachers 'Society, as well as its founder and chairman Yaroslav Hrytskovian, a Polish scholar of Ukrainian origin, is emphasized.

The directions and the educational achievements of schooling institutions in a multicultural environment, as well as the problematic issues relating to the functioning of the cultural and educational centres are considered.

Keywords: an educational activity; Ukrainian schooling; an assimilation process; Ukrainian community, national identity.

П остановка проблеми. За межами етнічної батьківщини проживають мільйони українців. Найширше представлені українські громади у Канаді, Росії, США. Численною є спільнота українців у Польщі. За даними МЗС тут проживає 31000 українців, за неофіційними даними цей показник $є$ значно вищим [5].

В умовах іншокультурного середовища збереження своєї національної самобутності, культури, мови є досить проблемною та має низку особливостей. Головними чинниками збереження національної ідентичності є послуговуваня рідною мовою, дотримання культурних традицій. Зарубіжні українці підтримують свою тотожність завдяки діяльності низки організацій. Це стосується і сфери українського шкільництва. Українські громадські, культурно-освітні товариства та школи функціонують у Польщі в умовах взаємодії титульної нації та української меншини.

Піклування про забезпечення національнокультурних та освітніх потреб закордонного українства є складовою освітньої політики 


\section{ЗАБЕЗПЕЧЕННЯОСВІТНІХПОТРЕБ ПРЕДСТАВНИКІВ УКРАЇНСЬКОӤ ГРОМАДИ У ЦЕНТРАХ ШКІЛЬНИЦТВА У ПОЛЫЩІ}

Української держави [8]. Проте поступові процеси асиміляції до суспільних обставин країни поселення спричиняють у багатьох випадках зменшення чисельності українців, які $\epsilon$ громадянами інших держав.

Впродовж тривалого періоду етнічні українці Польщі зберігають свою тотожність саме завдяки українським освітнім закладам. Тому для забезпечення мовно-культурних прав закордонних українців необхідною є державна підтримка українських культурних центрів та навчальних закладів [7].

Аналіз основних досліджень і публікацій. Значний внесок у дослідження генези українського шкільництва у Польщі зробили такі польські дослідники українського походження як С. Дзюбина, Р. Дрозд, С. Заброварний, М. Козак, О. Колянчук, Т. Марціняк, В. Мокрий, М. Сирник, I. Филипчак, Г. Халупчак, розглядаючи його у контексті суспільно-політичних реалій $\mathrm{XX}$ століття. Опрацюванню означеного питання присвячені дослідження Л. Биковської, Г. Білавич, А. Василюк, І. Павліва. Розвиток українського шкільництва у Польщі демонструє численні організаційно-педагогічні підходи; його системність забезпечує взаємозв'язок освітніх ланок навчально-виховного процесу. Існування розгалуженої низки освітньо-культурних центрів потребує аналізу й узагальнення. У цьому зв' язку багатим $є$ досвід педагогічної діяльності польського вченого українського походження Ярослава Грицковяна.

Мета статті - проаналізувати функціонування центрів українського шкільництва у Польщі та реалізацію ними освітніх потреб представників української меншості в іншомовному культурному просторі.

Виклад основного матеріалу. Розвиток українського шкільництва у Польщі у XX - на початку XXI ст. визначався низкою факторів, серед яких - політичні та суспільні процеси, нормативно-правова база щодо статусу та визнання прав нацменшин, освітні реформи Польської республіки.

Операція “Вісла" призвела до розсіяння українського етносу по всій території Польщі. Обмеження права компактного проживання українських громад в одному населеному пункті унеможливлювало створення їх культурних осередків, в тому числі й шкіл. Право українців на сповідування національних культурних та моральних цінностей було порушене. У протистоянні асиміляційним процесам українська громада створювала власні товариства й організації, які здійснювали освітньо-виховну діяльність і відстоювали їі право на власну культуру, мову, релігію.

Шкільництво української національної меншини стало складовою освіти в Польщі, втім його становлення позначено різними фазами. Безпосередньо післявоєнний етап (1945 - 1952 рр.) відзначався гуртуванням дітей українських родин у так званих “пунктах навчання", які легалізувалися упродовж 1952 - 1956 рр. у районах найбільшого скупчення українських родин. У 1956 р. українська спільнота офіційно здобула статус національної меншини, що дало можливість здійснити поступове розгалуження мережі українських освітніх закладів, у діяльності яких брав безпосередню участь Я. Грицковян. Суспільно-культурне життя української нацменшини, пожвавилось: відкривалися українські школи, функціонували українські класи у школах Польщі, окремі навчальні дисципліни читалися рідною мовою. Від 1968 р. українське шкільництво зазнає негативних тенденцій розвитку. У час посилення авторитаризму комуністична влада проголосила тезу про “монолітний національний характер" польської держави, що проявилося і в їі освітній політиці закритті малокомплектних шкіл, де навчалися діти української нацменшини. В 1980 - 1991 рр. відбувається демократизація суспільнополітичного життя в Польщі, що привело до послаблення тиску влади на функціонування українських осередків. Виникнення напочатку 80-х рр. руху “Солідарність” сприяло увиразненню прагнень української меншини до пожвавлення культурного життя, що збіглося із духовними запитами польського суспільства. Активізація діяльності українських культурно-освітніх осередків у Польщі, відродження громадськополітичного, культурно-освітнього життя, заснування ліцеїв, періодичних видань українською мовою, одержання нормативноправових основ освітньо-виховної діяльності шкільних осередків припадає на період 1991 2010 pp. Кінець XX - початок XXI ст. позначений законодавчим врегулюванням прав національних меншин на рідномовне навчання у дитячих дошкільних установах, школах, культурно-освітніх осередках. Створюються Комплекси шкіл 3 українською мовою навчання.

Динаміка становлення українського шкільництва у Польщі як системи залежала від суспільнополітичних факторів.

Суспільні утиски, що мали місце наприкінці 40-х та 50-х років, призвели до порушення традицій українського шкільництва у Польщі, яке консолідувалося передовсім довкола центрів 


\section{ЗАБЕЗПЕЧЕННЯ ОСВІТНІХПОТРЕБ ПРЕДСТАВНИКІВ УКРАЇНСЬКОЇ ГРОМАДИ УЦЕНТРАХ ШКІЛЬНИЦТВА У ПОЛЫЩІ}

духовності. Діяльність церковних осередків $є$ визначальною у справі підтримання традицій та забезпечення можливості вивчення рідної мови. Загалом, поєднання засад церковного і освітнього характеру постає типовою тенденцією для української діаспори.

Акції комуністичної влади спричинили руйнацію структур УГКЦ у Польщі. Культурноосвітнє життя українців зазнало втрат. Разом 3 вірниками у рамках акції "Вісла" переселяли й священиків, духівники перебували під наглядом, їх позбавляли права відправляти богослужіння українською мовою.

У процесі відновлення діяльності УГКЦ в Польщі певну роль відіграв і Примас Польщі С. Вишинський, який 14 березня 1957 року офіційно дозволив відправляти Богослужінння у східному обряді для українців, депортованих на північно-західні землі Польщі. Цьому декрету передували численні звернення з боку українських священиків. Таким чином, на 1957 рік припадає початок юридичного відновлення структур УГКЦ на території Польщі.

З відродженням церковного життя пов'язується й пожвавлення діяльності освітніх осередків урізних польських містах: Куляшне (1952), Перемишль та Краків (1957), Ярослав і Гребенне (1965).

В окремих містах (Бартошиці, Білий Бір, Гурові Ілавецьке, Лігниця, Перемишль, Варшава, Краків, Вроцлав, Люблін, Ольштин, Щецін, Гданськ, Кошалін, Колобжег, Слупськ, Битув, СтаргардЩецінський, Славно, Боболіце, Члухув) активно діяли церковні структури, які ефективно стимулювали розвиток українського шкільництва.

Завдяки зусиллям української громади було прийняте важливе суспільне рішення стосовно українського шкільництва. Воно припало на 1952 рік, коли Міністерство освіти Польщі ухвалило низку постанов, які дозволяли введення української мови в польських школах. Розглядалася можливість створення української освіти або класів $з$ українською мовою навчання.

Розпорядження Міністерства освіти від 20 серпня 1952 року, яке регулювало форми та сфери навчання українських дітей рідною мовою. Зважаючи на велике розсіювання представників української громади на значній території, основою навчання стали уроки української мови як додаткового предмету. Навчання можна було проводити для щонайменше 10 учнів протягом 3 годин на тиждень, починаючи 3 другого класу в школах або в комплектах. Встановлений поріг до 10 учнів у багатьох випадках спричиняв непереборні труднощі в організації навчальновиховного процесу [14, 219].
Розпорядження регулювало питання освіти українською мовою до 1956 року, а після змін, внесених в 1959 році, діяло до 1992 року. На його підставі розпочали діяти в 1952/53 навчальному році 24 пункти навчання для 487 дітей [4, 210]. Пункти навчання були єдиною формою зорганізованого навчання українських дітей рідною мовою у 1952 - 1956 рр.

У 1956 р. українська спільнота офіційно здобула статус національної меншини, що дало можливість здійснити поступове розгалуження мережі українських освітніх закладів за рахунок пунктів навчання, початкових шкіл, гімназій, шкільних комплексів, ліцеїв. Суспільно-культурне життя української нацменшини, пожвавилось: відкривалися українські школи, функціонували українські класи у школах Польщі, окремі навчальні дисципліни читалися рідною мовою.

У розпорядженні Міністерства Освіти Польщі № 505/6456/ 56 від 4 грудня 1956 року містився дозвіл на утворення пунктів навчання української мови за умови, якщо кількість учнів в такому пункті буде не менше семи. Зміна умов життєдіяльності української спільноти дала поштовх очевидному збільшенню числа учнів.

Наприкінці 50-х - 60-х рр. українська меншина на території всієї Польщі мала 6 початкових шкіл 3 рідною мовою навчання та 2 загальноосвітні ліцеї: в Лігниці та Гурові Ілавецькому. У 1963/1964 навчальному році українську мову у різних формах, особливо на позакласних заняттях, вивчало 3283 учнів. У 1983/1984 році існувало два українських загальноосвітніх ліцеї, у двох початкових школах функціонували окремі класи 3 українською мовою навчання (Білий Бір і Бані Мазурські). До того ж, у 25 польських початкових школах проводилося навчання української мови на рівні факультативу [15].

За свідченнями Я. Грицковяна, в 1960/61 навчальному році діяло тільки 10 шкіл, де процес навчання здійснювався українською мовою, а також 132 школи, в яких українська мова викладалася як предмет. Відтоді число українських шкіл зменшувалося, а разом з цим обмежувалися потреби українського шкільництва.

На кінець 50-х - початок 60-х рр. припадають перші контакти учителів з Польщі з Україною, а саме на рівні організації курсів вдосконалювання кваліфікації. Це спричиняло зміцнення прагнень ширше впроваджувати українську мову у навчальний процес. Проте посилювався також ідеологічний натиск на вчителів. До того ж навчальні підручники містили матеріал, схвалений цензурою. Здійснювався нагляд за роботою освітян, у тому числі за Я. Грицковяном як 


\section{ЗАБЕЗПЕЧЕННЯ ОСВІТНІХПОТРЕБ ПРЕДСТАВНИКІВ УКРАЇНСЬКОЇ ГРОМАДИ УЦЕНТРАХ ШКІЛЬНИЦТВА У ПОЛЬЩІ}

інспектором Інституту вдосконалення кваліфікації вчителів. Він був відповідальним за навчальний процес у школах з викладанням дисциплін мовами національних меншин.

Загалом суспільно-культурна діяльність української національної меншини набула інтенсивного пожвавлення у $1956-1968$ рр. У рамках УСКТ працювало п'ять воєводських відділень, зокрема, в Гданську, Вроцлаві, Ольштині, Кошаліні, Щеціні, а також тридцять повітових відділень та 1200 регіональних гуртків. Культурно-освітню роботу проводили понад п'ять тисяч членів УСКТ. Проте після “березневих подій” 1968 року ця динаміка зазнала суттєвого послаблення, коли комуністична влада проголосила тезу про “монолітний національний характер” польської держави, що проявилося і в освітній політиці- закритті малокомплектних шкіл, де навчалися переважно діти української нацменшини.

Суспільно-політичні обставини 70-х рр. спричинили значне зменшення шкіл різних національних меншин. Початок 80-х рр. ознаменувався тим, що функціонували всього 4 школи з українською мовою навчання та 27 шкіл, в яких українська мова викладалася як предмет. Отже, рідну мову вивчали всього 822 особи [9, 122]. Тут діяли згадані програмні настанови до 1989 року, власне, як у польських школах.

Декларативне утвердження “моральнополітичної єдності польського народу” спричинило суттєві негативні зміни як стосовно організаційної діяльності, так і культурно-освітньої роботи УСКТ. 3 боку партійного апарату ПОРП та Міністерства внутрішніх справ посилився контроль та здійснювалося безпосереднє втручання у процес здійснення положень Статуту УСКТ. Формалізовані заходи передбачали творення враження розквіту національної спільноти в умовах соціалістичної дійсності.

Виникнення руху “Солідарність” пожвавило на початку 80-х рр. прагнення української меншини до покращення культурного життя, що співпало 3 духовними запитами польського суспільства.

Вирішальне значення для поліпшення роботи на ниві українського шкільництва мали політичні події у 1989 р. Крах комуністичної ідеології та поява незалежної України спричинили трансформацію суспільних відносин. Це зумовило і зміну стосовно апробації інноваційних підходів, спрямованих на розвиток українського шкільництва з урахуванням національних традицій виховання підростаючого покоління. Ці заходи, що реалізовувались у співпраці з інституціями 3 України, протидіяли асиміляційним процесам. Вони спонукали українську спільноту у Польщі зміцнювати свої освітні осередки $[1,8]$.

Тенденція послаблення щодо вивчення української мови у 80 - 90-х рр. зумовлювалася не стільки суспільно-політичними, як соціальними причинами. У багатьох випадках оплата за навчання була надто високою для українських родин $[12,6]$. Проте основна від’ємна причина полягала в асиміляційних процесах, що спричинило зменшення кількості активних носіїв української мови в Польщі. Гальмівним для розвитку українського шкільництва був також високий відсоток розриву взаємодії між українськими родинами в умовах тотального розпорошення в багатьох воєводствах. Я. Грицковян уважав “розсіяність українських родин” однією 3 найбільших вад, що були на перешкоді діяльності вчителів. “3 огляду на малу кількість дітей, підкреслює педагог, - появляються клопоти при організації навчальних груп, при комплектуванні дітей двох, трьох, а то й більше класів" [3, 3$]$.

3 метою протистояння явищу асиміляції Об’єднання українців у Польщі (ОУП), правонаступник УСКТ, здійснило низку заходів. Зокрема, в офіційних документах ОУП зазначена необхідність дбати про виховання українських дітей у національному дусі, плекання почуттів національної ідентичності. Все це невіддільне від реалізації завдань українського шкільництва на території Польщі, на що націлює “Програма Об’єднання українців у Польщі” [7, 5-6]. Ця програма узгоджується 3 положеннями Статуту Українського вчительського товариства (УВТ), очолюваного Я. Грицковяном впродовж багатьох років. Вони охоплюють стратегічні дії стосовно вивчення рідної мови, яка відтворює чи не найбільший пласт культури українського народу. Звідси - природна потреба, як підкреслив Я. Грицковян, збільшення кількості пунктів навчання української мови $[4,1]$. Вони стали в Польщі поширеною формою прилучення шкільної молоді до рідної мови. Міністерство національної освіти Польщі (МНО) 4 травня 1990 року підтримало пропозиції ОУП щодо проблемних питань вивчення української мови, забезпечення шкільних осередків навчальною літературою.

Заслуговує на увагу нормативний акт МНО, який регламентував навчання українською мовою та іiі оволодіння. Йдеться про “Розпорядження міністра освіти від 24 березня 1992 року у справі організації освіти, яка уможливить підтримання почуття національної, етнічної та мовної ідентичності учнів, які належать до національних меншин” [13]. У відповідності з цим документом директори шкіл, керівники дошкільних установ 


\section{ЗАБЕЗПЕЧЕННЯОСВІТНІХПОТРЕБ ПРЕДСТАВНИКІВ УКРАЇНСЬКОӤ ГРОМАДИ УЦЕНТРАХ ШКІЛЬНИЦТВА У ПОЛЫЩІ}

мали можливість відкривати навчання рідною мовою (або іiі вивчення) за письмовою заявою батьків або опікунів дітей, а учням старших класів надавалося право самим звертатися $з$ подібними заявами.

Практика ведення уроків рідною мовою набула традиції і в дошкільних установах.

Важливою для розвитку українського шкільництва в Польщі стала ухвала МНО Польщі від 7 березня 1991 року [11]. Вона регулювала співвідношення кількості годин у школах 3 українською мовою навчання, де велися уроки польської мови, польської літератури та історії Польщі.

У 90-х рр. система українського шкільництва в Польщі характеризувалася діяльністю чотирьох основних українських шкіл - в Білому Борі, Бартошицях, Перемишлі та Банях Мазурських із загальною кількістю 432 учні, а також трьох загальноосвітніх ліцеїв - у Білому Борі, Гурові Ілавецькому та Лігниці. Загальна кількість учнів складала 350 осіб. Чотири загальноосвітні ліцеї 3 українською мовою навчання відіграли значну роль у справі виховання представників нових поколінь свідомих українців.

У 1992 - 1993 навчальномуроці функціонували 83 пункти навчання української мови, які охоплювали 1756 школярів. Із загальної чисельності 43 пункти, де навчалось 859 учнів, були зареєстровані в органах освіти як міжшкільні та шкільні пункти, тобто утримувалися державою. Решта 40 пунктів 3 897 учнями утримувалися на кошти громад. Вони розміщувалися у світлицях ОУП, а також у прицерковних приміщеннях. На сучасному етапі у Польщі функціонує 88 українських недільних шкіл, де навчається близько 2200 учнів [5, 28].

Загалом можемо зазначити, що вивчення української мови у Польській республіці відбувається на всіх освітніх ланках: дошкільних закладах, початкових школах, гімназіях та загальноосвітніх ліцеях. На даному етапі у Польщі функціонують п'ять комплексів українських шкіл (“Комплекс загальноосвітніх шкіл ім. Т. Шевченка в Білому Борі”; “Комплекс шкіл ім. М. Шашкевича в Перемишлі”; “Комплекс шкіл ім. Лесі Українки в Бартошицях"; “Комплекс шкіл в Гурові Ілавецькому"; “Комплекс шкіл в Лігниці"), що включають 56 загальноосвітніх навчальних закладів та чотири ліцеї з українською мовою навчання. 32011 року українські класи були відкриті при комплексі загальноосвітніх шкіл у Більську-Підляському [6, 186].
Українське шкільництво у Польщі має як незаперечні досягнення, так і проблемні питання. Примітним є звіт УВТ за 2000 рік, в якому названі першочергові проблеми українського шкільництва в Польщі: а) різке скорочення кількості учнів у школах і пунктах вивчення української мови, що зумовили несприятливі демографічні явища та окремі положення, викликані новою реформою освіти; б) розформування деяких шкільних осередків, що пояснюється соціальними причинами в українських родинах, а також недостатнім фінансуванням шкіл та установ; в) потреба у нових програмах, підручниках; г) необхідність організації курсів підвищення кваліфікації; г) розширення доступу до української преси та мас-медіа; д) недостатня кількість годин, виділених на позашкільну діяльність, необхідну у процесі виховання національно свідомих поколінь; е) недостатність виділених фондів на вдосконалення вчителів в Україні; є) відсутність у Міністерстві національної освіти Польщі відповідального координатора у справах українського шкільництва [11].

У навчанні дітей з українських сімей було i залишається проблемним навчально-методичне забезпечення. Оновлення програм та укладення шкільних підручників є одним із показників перебудови освітньо-виховного процесу. Проте, за спостереженням М. Сирника, чимало програм не відповідають вимогам нових розпоряджень та потребам часу. Змістовий компонент передбачає його установку на розвиток національної гордості в інонаціональному середовищі. М. Сирник пропонує виховувати “здоровий, практичний патріотизм” [10], враховуючи зацікавлення та погляди молоді, вибудовуючи позитивний образ українця.

Висновки. Освітнім осередкам, де плекається любов до рідної мови, культури та звичаїв належить істотна роль у збереженні почуттів національної ідентичності в інонаціональному середовищі. Не зважаючи на складні умови, педагогам та громадським діячам українського походження вдалося організувати діяльність низки закладів українського шкільництва у Польщі. Подальший розвиток освітніх традицій закордонного українства залежить і від його підтримки з боку Української держави.

\section{ЛІТЕРАТУРА}

1. Грицковян Я. Київ - Варшава: справи освіти національних меншостей / Ярослав Грицковян // Наше слово. - 1998. - № 16. - С. 8.

2. Грицковян Я. Методика навчання української 


\section{ЗАБЕЗПЕЧЕННЯ ОСВІТНІХПОТРЕБ ПРЕДСТАВНИКІВ УКРАЇНСЫКОӤ ГРОМАДИ У ЦЕНТРАХ ШКІЛЬНИЦТВА У ПОЛЫЩІ}

мови та літератури. Посібник для вчителів української мови в Польщі / Ярослав Грицковян. - Варшава, 1998. - 231 с.

3. Грицковян Я. Українське шкільництво в потребі / Ярослав Грицковян // Наше слово. 1992. - № 49. - С. 1 .

4. Дрозд Р. Історія українців у Польщі в 1921 1989 роках / Роман Дрозд, Богдан Гальчак, Ірина Мусієнко. - Харків : Золоті сторінки, 2013.- 272 с.

5. Мазука Л.І. Українська держава та світове українство: актуальні питання, потенціал та перспективи взаємодії / Л. І. Мазука [Електронний ресурс]. - Режим доступу: http:// www. niss. gov. ua/content/articles/files/ukr_depzh8f19d. pdf.

6. Петрик В. Культурно-освітня діяльність українців у Польщі у час системної трансформації / В. Петрик // Міжнародний науковий форум: соціологія, психологія, педагогіка, менеджмент. Вип. 5: Збірн. наук. праць. - К.: Вид-во НПУ ім. М.П. Драгоманова, 2011. - С. 183 - 189.

7. Програма Об'єднання українців у Польщі // Наше слово. - 2001. - № 6. - 11 лютого. - С. 5-6.

8. Про закордонних українців. Закон України [Електронний ресурс]. - Режим доступу: http:// zakon.rada.gov.ua/laws/show/1582-15

9. Сирник М. Стан навчання української мови уПольщі після виселення 1947 року/М. Сирник / / Українознавство. - 2005. - № 4. - С. 122-128.

10. Сирник М. Навчання української мови у Польщі. - Марко Сирник / http://www.naszeslowo.pl/navchannya-ukrayinskoyi-mowi-v-polshhi/

11. Стан, проблеми та перспективи розвитку українського шкільництва в Республіці Польща звіт УВТ [Електронне видання] / Режим доступу:http://www.interklasa.pl/portal/dokumenty/ r__mowa/strony_ukr/statystyka01.htm

12. Щерба I. Другий етап реформи і українське шкільництво / І. Щерба // Наше слово. - 2000. № 48. - 26 листопада. - С. 6.

13. Rozporzadzenie Ministra Edukacji Narodowejzdnia 24 marca 1992 roku w sprawie organizacji kształcenia umożliwiającego podtrzymywanie poczucia tożsamości narodowej, etnicznej uczniów należących do mniejszowych [Електронне видання] / Режим доступу: http:// www.interklasa.pl/portal/dokumenty/ r_ mowa/strony_pol/prawo01.htm

14. Ukraina - Polska. Kultura. Wartości. Zmagania duchowe / Pod red. R. Skeczkowskiego, R. Drozda, J. Hryckowiana, M. Zymomrii. Koszalin, 1999. - $311 \mathrm{~s}$.

15. Zymomrya M. Szkolnictwo mniejszości ukraińskiej jako element podtrzymania poczucia tożsamości narodowej / M. Zymomrya, A. Kręźołek, O. Jurosz // Edukacia jutra XIII Tatrzańskie seminarium nuakowe / Red. naukowa: K. Zatoń, T. Koszczyc, M. Sołtysik. - Wrocław, 2007. - T. 2. - S. $225-230$.

\section{REFERENCES}

1. Hrytskovian, Ya. (1998). Kyiv - Warshava: spravy osvity natsionalnykh menshostei [Kyiv Warsawa: Issues of Education of National Minorities]. Nashe slovo, no.16, p. 8. [in Ukrainian].

2. Hrytskovian, Ya. (1998). Metodyka navchannia ukrainskoi movy ta literatury. Posibnyk dlia vchyteliv ukrayinskoi movy v Polshchi [Methods of teaching the Ukrainian language and literature. A Guide for Teachers of Ukrainian in Poland]. Varshava Publ., 231 p. [in Ukrainian].

3. Hrytskovian, Ya. (1992). Ukrainske shkilnytstvo v potrebi [Ukrainian schooling in need]. Nashe slovo, no. 49, p. 1. [in Ukrainian].

4. Drozd, R., Halchak, B. \& Musiienko, I. Istoriia ukraintsiv u Polshchi v 1921 - 1989 rokakh [The history of Ukrainians in Poland in 1921 - 1989]. Kharkiv: Zoloti storinky, 272 p. [in Ukrainian].

5. Mazuka, L.I. Ukrayinska derzhava ta svitove ukrainstvo: aktualni pytannia, potentsial ta perspektyvy vzaiemodii [Ukrainian state and world ukrainian community: topical issues, potential and perspectives of interaction]. Available at: http: // www. niss gov ua / content / articles / files / ukr_depzh-8f19d. pdf [in Ukrainian].

6. Petryk, V. (2011). Kulturno-osvitnia diyalnist ukraintsiv u Polshchi u chas systemnoi transformatsii [The cultural and educational activity of Ukrainians in Poland at the time of system transformation]. International scientific forum: sociology, psychology, pedagogy, management. Vol. 5, Journal of scholarly works. Kyiv: M.P. Drahomanov NPU Publ., pp. 183 - 189. [in Ukrainian].

7. Prohrama Obiednannia ukraintsiv u Polshchi (2001). [Program of the Ukrainian Society in Poland]. Nashe slovo, no. 6., pp. 5-6. [in Ukrainian].

8. Pro zakordonnykh ukraintsiv. Zakon Ukrainy [On foreign Ukrainians. Law of Ukraine]. Available at: http://zakon.rada.gov.ua/laws/show/1582-15 [in Ukrainian].

9. Syrnyk, M. (2005). Stan navchannia ukrayinskoi movy u Polshchi pislia vyselennia 1947 roku [The State of Learning Ukrainian in Poland after the Deportation of 1947]. Ukrainian Studies, no. 4, pp. 122-128. [in Ukrainian].

10. Syrnyk, M. Navchannya ukrayinskoyi movy u Polshchi [Learning Ukrainian in Poland]. Available at: http://www.nasze-slowo.pl/navchannyaukrayinskoyi-mowi-v-polshhi/ [in Ukrainian].

11. Stan, problemy ta perspektyvy rozvytku ukrayinskoho shkilnytstva v Respublitsi Polshcha - 
zvit UVT [State, problems of and prospects for the development of Ukrainian schooling in the Republic of Poland - UTS report]. Available at: http: www.interklasa.rl/rortal/dokumenty/r__mowa/ strony_ukr/statystyka01.htm [in Ukrainian].

12. Shcherba, I. (2000). Druhyi etap reformy i ukrayinske shkilnytstvo [The Second Stage of Reform and Ukrainian Schooling]. Nashe slovo, no. 48, p. 6. [in Ukrainian].

13. Rozporzadzenie Ministra Edukacji Narodowejzdnia 24 marca 1992 roku w sprawie organizacji kształcenia umożliwiającego podtrzymywanie poczucia tożsamości narodowej, etnicznej uczniów należących do mniejszowych [Regulation of the Minister of National Education (March 24, 1992) on the organization of education of pupils belonging to minorities to maintain their national and ethnic identity]. Available at: http:// www.interklasa.pl/portal/dokumenty/ r mowa/strony pol/prawo01.htm [in Polish].

14. Ukraina - Polska. Kultura. Wartości. Zmagania duchowe (1999). [Ukraine - Poland. Culture. Values. Spiritual strivings]. Editing by R. Skeczkowski, R. Drozd, J. Hryckowian, M. Zymomrya. Koszalin: INRTO-DRUK, 311 p. [in Polish].

15. Zymomrya, M., Kręźołek, A., \& Jurosz, O. (2007). Szkolnictwo mniejszości ukraińskiej jako element podtrzymania poczucia tożsamości narodowej [Education of the Ukrainian minority as an element in maintaining a sense of national identity]. Education of tomorrow. XIII-th Tatrzańskie scientific seminar. Editing by K. Zatoń, T. Koszczyc, M. Sołtysik. Wroclaw,Vol. 2, pp. 225-230. [in Polish].

Стаття надійшла до редакції 17.09.2018

\section{УДК 378:371.3(73) \\ DOI:}

Наталія Тимощук, кандидат філологічних наук, доцент кафедри украйнської та іноземних мов Вінницького національного аграрного університету

\section{ВИЩА АГРАРНА ОСВІТА США: ТЕОРЕТИКО-МЕТОДОЛОГІЧНИЙ АСПЕКТ}

У статті розглянуто окремі аспекти вищої аграрної освіти США. Виявлено, щуо сталий розвиток сільського господарства - основоположний фактор формування нової парадигми вищої аграрної освіти США. Вища аграрна освіта США організована за шістьма напрямами (програмами): агробізнес, сільськогосподарські виробничі прочеси, сільськогосподарська техніка, садівничтво, сільськогосподарські ресурси і лісництво, переробка сільськогосподарської продукиії. Безперечною перевагою американської вищоі освіти є ї̈ надзвичайна гнучкість щзодо способів, форм, методів і темпів навчання.

Ключові слова: вища аграрна освіта США; сталий розвиток сільського господарства; децентралізація; диверсифікація; змішане навчання.

Табл. 1.Літ. 10.

Nataliya Tymoshchuk, Ph.D.(Philology), Associate Professor of the Ukrainian and Foreign Languages Department Vinnytsya National Agrarian University

\section{THE HIGHER AGRARIAN EDUCATION IN THE USA: THE THEORETICALAND METHODOLOGICALASPECT}

The article considers some aspects of higher agrarian education in the USA. It reviles that sustainable agriculture is the fundamental factor in the formation of a new paradigm of higher agricultural education in the United States. The US agricultural higher education is organized in six directions (agendas), i.e. agribusiness, agricultural production processes, agricultural machinery, horticulture, agricultural resources and forestry, agricultural products processing. There are tendencies for further modernization and democratization of higher agricultural American education, changes in the academic background of the educational system. Decentralization of decisions; individual training; elective subjects; considerable attention to diagnostics and forecasting; training has a proactive character; integrated plans and programs; diversification of education; distance training; systematic approach are the main characteristics of higher agrarian education in the USA. The educational programs of higher agrarian institutions are rather flexible; it increases the quality training of specialists in the agricultural sector. The undoubted advantage of American higher education is its extraordinary flexibility in terms of methods, forms and learning styles. Curriculums provide students with a basic agricultural knowledgee. Practical trainings allow students to gain experience at agricultural or industrial enterprise in the agrarian sector.

Keywords: higher agrarian education in the USA; sustainable agriculture; decentralization; diversificatio; blended education.

П остановка проблеми. Важливим напрямом модернізації української вищої освіти є її відповідність вимогам світових освітніх стандартів. Нині у контексті освітніх реформ значна увага приділяється пошуку нових форм і напрямів реформування закладів 